\title{
Læger og kirurger i Aabenraa i slutningen af 1700-tallet
}

\section{Af Johannes Brix}

Set med vor tids øjne var det en meget begrænset lægehjælp, som stod til rådighed for befolkningen i slutningen af 1700-årene. I denne artikel gengives en samtidig skildring af de lægelige forhold i Aabenraa omkring 1796. Det er barsk læsning, her udgivet med lage Johannes Brix' indledning og kommentar.

Den nedenfor gengivne, noget barske artikel om medicinalforholdene i Aabenraa i slutningen af 1700-tallet er hentet fra tidsskriftet »Physicalsk-oeconomiske og medico-chirurgiske Bibliothek for Danmark og Norge«, juli 1796. I daglig tale kaldte man tidsskriftet »Journalen med den lange titel«. Det udkom under det noget besværlige navn i perioden 1794-1797. Fra 1797 og frem til 1807 udkom tidsskriftet $i$ anden form og med anden redaktion.

Artiklerne var som regel anonyme og oftest originale. Tidsskriftet blev udgivet af et "selskab « af oplysningsmænd, som veterinæren Erik Nissen Viborg (1759-1822), den alsidige oplysningsmand og naturforsker Carl Gottlob Rafn (1769-1808) samt lægen Ole Hieronymus Mynster (1772-1818), dr.med. 1797 og ekstraordinær professor ved Københavns Universitet 1805. Den sidste og formentlig flittigste skribent $\mathrm{i}$ denne gruppe var Johan Daniel Herholdt (1764-1836)'.

Herholdt var født i Aabenraa, hvor faderen i en årrække havde virket som kirurg. Det store lokalkendskab afslører Johan Daniel Herholdt som den mest sandsynlige forfatter til den her gengivne artikel. Han var på det tidspunkt, artiklen fremkom, divisionskirurg i Søværnet. Han blev imidlertid senere student, dr.med. og professor ved det medicinske fakultet under Københavns Universitet.

Herholdts ærinde med at publicere artiklen har næppe været objektivt at gengive de medicinale forhold i Aabenraa på det aktuelle tidspunkt. Snarere må den anses for at være et polemisk indlæg $\mathrm{i}$ den årelange strid mellem kirurger og læger. Uoverensstemmelserne var tilspidsede efter etableringen af Det kirurgiske Akademi i København i 1785. De i artiklen omtalte læger var ikke typiske repræsentanter for lægestanden på det daværende tidspunkt. Ikke desto mindre benyttede medicinalhistorikeren Gordon Norrie (1855-1941) ukritisk den lille barske fodnote, som indleder artiklen (se nedenfor side 50), 
som kilde i sin bog "Chirurger og doctores. Et kritisk Bidrag til Lægeuddannelsens Historie i Danmark før 1800 «. Bogen var ment som dokumentation for Gordon Norries opfattelse af, at lægerne i de tidligste tider ikke havde viden om kirurgi og ej heller var i stand til at udøve nogen kirurgiske færdigheder. Han går endda så vidt som at hævde, at lægerne ikke måtte beskæftige sig med kirurgiske indgreb. Herholdts artikel der gengives nedenfor er ikke blevet citeret, siden den fremkom 1796. Kun noten i Norries bog er ukritisk gengivet ${ }^{2}$.

Det vil nok være rimeligt yderligere at forudskikke den bemærkning, at medicinallovgivningen i Hertugdømmerne på adskillige områder afveg fra den der var gældende i Kongeriget ${ }^{3}$.

"Brev til Udgiverne af det medicochirurgiske Bibliothek om Medicinalvæsnets nuværende Tilstand i Apenrade.

Mine Herrer! ... [Efter nogle få sætninger, der ikke har interesse for det følgende, fortsættes]: "Medicinalvæsnet i Amterne Apenrade og Lygum Kloster bestyres af en Physicus Hr. Dr. Wiggers ${ }^{5}$, hvis Navn De, vist nok uventet, har fundet paa Primitice flora Holsatice, der som hele Verden veed, har $\mathrm{Hr}$. Professor Weber til Forfatter ${ }^{6}$. Under hans Opsigt praktisere endnu tvende kongelig privilegerede Chirurger ${ }^{7}$, en gammel Mand Hr. Zehr ${ }^{8}$ og en yngre Hr. Hess ${ }^{9}$. Paa ingen af disse har Akademiet, at jeg skal betjene mig af deres eget Udtryk, offentligen trykt sit Dueligheds Stempel. De ere begge, efter Indretningen for $1785^{10}$, privat examinerede af Stedets Physikus i Chirurgien, den Deel af Lægekonsten, hvori man her vil vide, at hverken den forrige, sal. D. Schonk ${ }^{11}$, eller den nuværende D. Wiggers ved Praktik eller Skrivter, selv have lagt nogen Kundskab eller Færdighed for Dagen*.

Chirurgerne ere tillige Amtsbarberer, indlemmede i det Flensborger Barbeeramt ${ }^{14}$. Ingen af dem har fast Lon.

D. Wiggers, som egentligen skulde besørge den medicinske Praxis, har især af Mangel paa Klogskab ikke vidst at vinde Borgernes Tillid, og bruges derfor kuns lidet. Den almindelige chirurgiske Praxis bestyre Chirurgerne temmelig vel; Frakturer, som her, hvor Egnen er bjerget og Hestene modige, forefalde

\footnotetext{
* Man fortaller her om D. Schonk, der ved forefaldende Operationer fandt sig beføjet til at staae Chirurgerne bi med Raad og Daad, forunderlige Ting: Uden selv at kunne fore den chirurgiske Kniv, paatog han sig at bestemme, naar, hvor og hvorledes den skulde føres. Han tog, som et $\emptyset$ jevidne har fortalt, almindelig Heisters Chirurgie ${ }^{12}$ med til den Syges Bolig, oplæste i Patientens Nærværelse med myndig Røst, hvorledes det til Operationen fornødne Aparat skulde ordnes, oplæste videre af Bogen, hvorledes Operationen skulde forrettes, og bad derpaa Chirurgen at skjere i Jesu Navn. Under Forretningen saa han afvexlende på Operatørens Haand og i Heister Chirurgie, som han bestandig holdt opslagen for sig. Man tænke sig den Skræk en saadan Exekution maa have indjaget den Lidende ${ }^{13}$.
} 


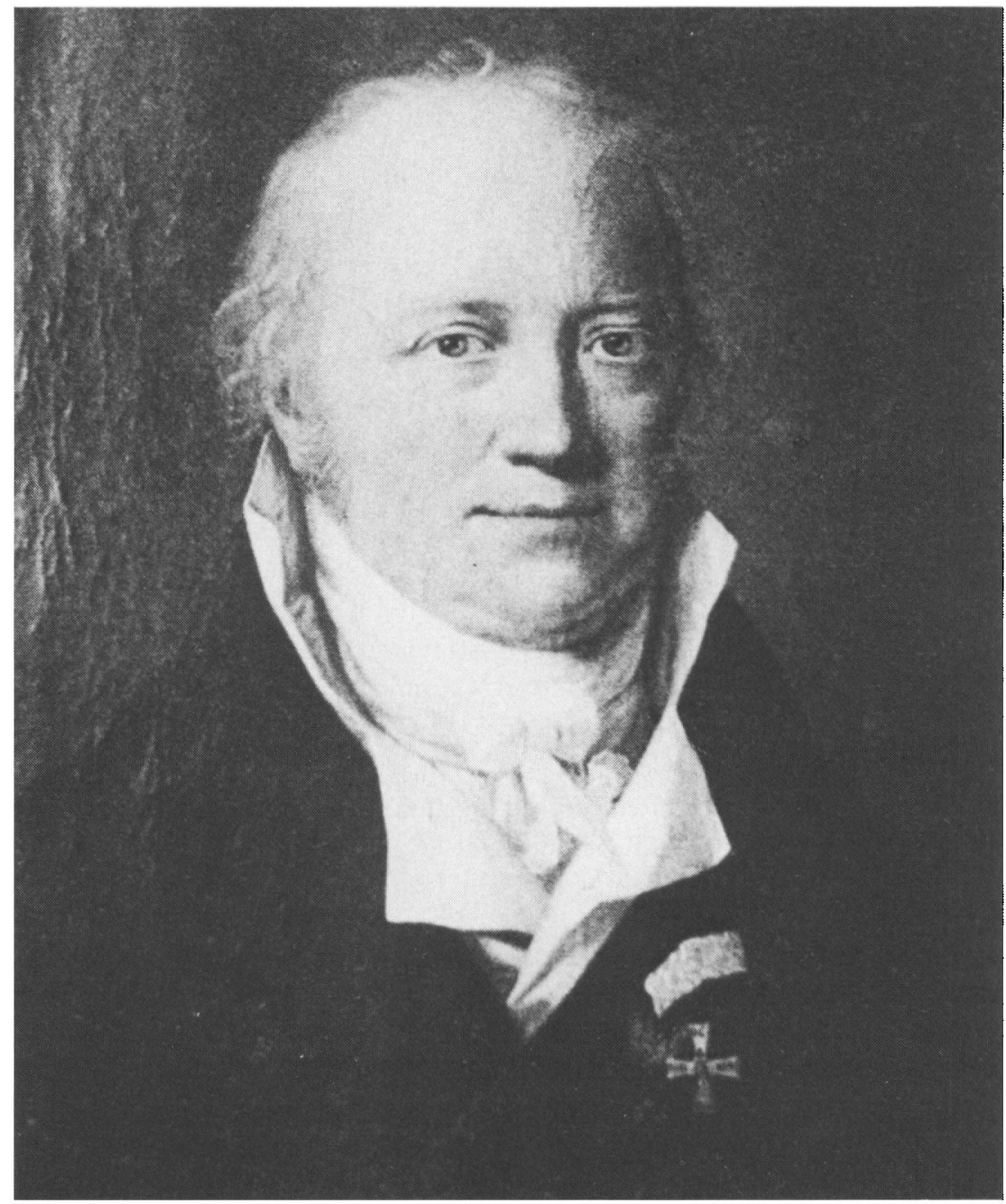

Johan Daniel Herholdt, som er den formentlige forfatter til artiklen udgivet her, var fodt i Aabenraa. Han var uddannet kirurg, men blev en af de helt store koryfaer inden for lagevidenskaben i Danmark $i$ begyndelsen af 1800-tallet. Billedet er malet af den kendte portrattor, sonderjyden $C$. A. Jensen (1792-1879), i 1836, efter Herholdts dod. Maleriet forestiller Herholdt $i$ 60-ärsalderen. Maleriet befinder sig i dag pd Statens Museum for Kunst.

hyppigen, helbrede de især godt. Man seer næsten aldrig en krumbenet her $\mathrm{i}$ Egnen. Med Medicinens Udøvelse, hvortil de ikke ere beføjede, befatte de sig kun sjelden. I vanskeligere saavel medicinske som chirurgiske Tilfalde, er det Skik her blandt de Formuende at hente en Læge fra en af de nærmeste 
Kjøbstæder ${ }^{15}$, og blandt disse staaer Hr. Stabschirurg Schmidt fra Hadersleben i største Anseelse' ${ }^{16}$.

Doctor Krikou den aldre fra Tøndern ${ }^{17}$, skal først have indført Koppeympningen her paa Stedet ${ }^{18}$, hvorved han for nogle Aar siden gjorde sig fortrinlig bekjendt, og fortjente en Deel Penge. Byen har $i$ øvrigt et par Gjordemødre $^{19}$ og sit eget Apothek ${ }^{20}$.

Hvad man almindeligen seer paa de Steder, hvor den første Læge ikke er i Anseelse, har jeg desværre ogsaa bemærket her. Mængden er endnu indtaget af medicinske Fordomme, dysser sig ofte hen $i$ et bedrageligt Haab om Guds umiddelbare Bistand, og troer sig forhexet, naar Midlerne ikke strax ville hjelpe, uden Hensyn til Sygdommens Natur. Qvaksalveriet er steget til en ualmindelig Højde. Næsten enhver som trykkes af Armod, vover et eller andet Forsøg paa denne Bane. Skarpretterne der som oftest - Gud maa vide hvorfor - have let ved at komme for Orde som duelige Chirurger, træde ogsaa, saalænge man kan huske, i Æskulaps Fjed. Den sidst Afdøde ved Navn Røsler ${ }^{21}$, skal endog have erholdt Tilladelse hertil fra vedkommende højere Steder. Hans Datter, som er gift med Styrmand Claus Clausen, har siden Faderens Død offentlig og frit udøvet Chirurgien til betydelig Tab for de privilegerede Chirurger. Disse toge deraf i Aaret 1792 Anledning til at klage for Magistraten, hvorpaa det ved $5 \mathrm{Rd}$. Straf blev Praktikantinden forbudet, at befatte sig med Kuren af chirurgiske Sygdomme.

Dette holdt Hende ikke tilbage, men gjorde hende mere trodsende; hun blev ved som tilforn, rejste paa Landet og paatog sig Kurer overalt. Endeligen blev hun i Fjor Sommer atter anklaget, og overbeviist om, at hun modtvilligen havde overtraadt $\emptyset$ vrighedens Befaling. Hun havde intet til sin Undskyldning uden dette, at Menneskekjerlighed og Uegennytte havde været Drivefjedrene til hendes Handlinger. Hun blev alvorligen erindret om den fastsatte Straf, og saavel Aareladen som anden chirurgisk Forretning blev hende forbuden, uden Hensyn til om hun derfore lod sig betale eller ikke. Siden den Tid fortæller man, at hun i Stilhed lader en Cirkulaire løbe omkring, hvorpaa hendes Velyndere tegne deres Navne, og med dette anbefalende Document haaber hun, som hver da letteligen seer uden al Grund og tvertimod den kongelige Anordning, at blive priveligeret som Qvaksalver. Physikus selv skal ikke være Madame Klausen ugunstig; han betroer hende endog til at aarelade i sit eget Huus.

Foruden denne Dame, som er den første, findes der endnu mangfoldige andre Qvaksalvere. Saaledes, at jeg skal nævne nogle, en Degn fra Loits Sogn, som dagligen fylder Apotheket med en anseelig Mængde Recepter ${ }^{22}$. Fremdeles en Kludekræmmer, som selv henter Medicamenter paa Apotheket, og forbruger dem uden Sky, saavel i Byen som paa Landet. Endvidere en gammel Bager, 


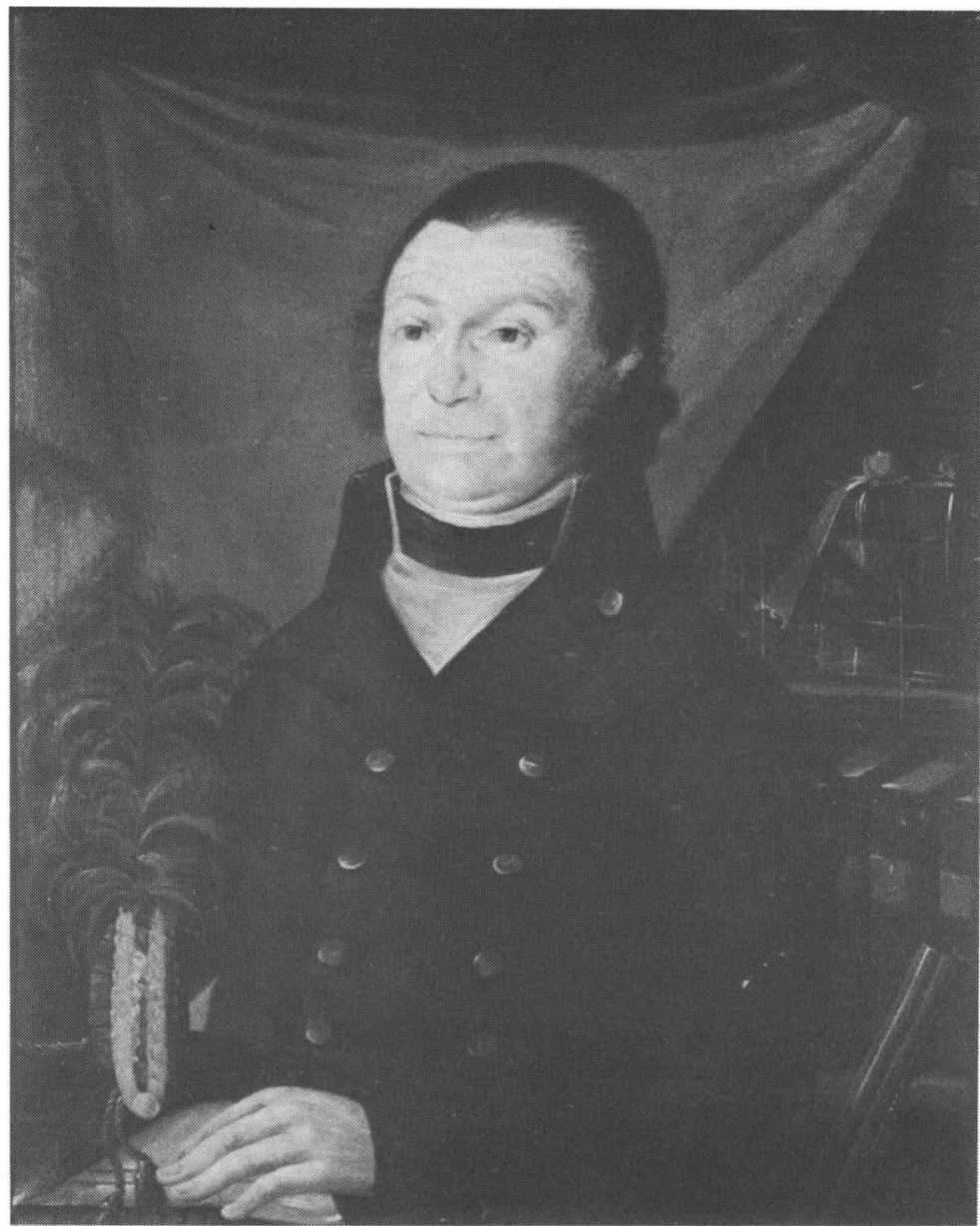

Claus Hess (1755-1818) er en af de få kirurger i 1700-årene, som blev portratteret. Dette maleri er fra 1805 og skyldes Aabenraa-maleren Jes Jessen. Hess er ifort Aabenraa Skyttelaugs gallauniform, med symboler både på skyttelauget og kirurgerhvervet. Til venstre ses skyttelaugets hat med fjerbusk, til højre stikker bøssepiben op foran en reol med bøger og medicinflasker. Maleriet findes $i$ dag $i$ Schleswig-Holsteinisches Landesmuseum på Gottorp slot. En kopi ejes af Aabenraa Skyttelaug. Her gengivet efter Lars N. Henningsen: Aabenraa Skyttelaug 1734-1984, 1984.

som beskuer Urinen og uddeler Lægemidler; og for at fylde Listen, en engelsk Urmager, som befatter sig med at føle Pulsen og at meddele sine medicinske Urmagerkundskaber ${ }^{23}$.

Paa kloge Koner fejler det ikke heller paa Landet heromkring, hvoraf især een for en halv Snes Aar siden, har gjort sig berømt ved at helbrede unge 
Piger, der ved at læse Siegvart og Consorter havde tabt deres Rolighed ${ }^{24}$. De Midler hvormed hun har gjort de hældigste Kurer, skulle især have været Generis masculini.

Til Slutning maa jeg endnu meddele $\mathrm{m}$. Hr. en Efterretning, som er saa vigtig, at jeg troer den fortjener enhver duelig Læges og Videnskabselskers besynderlige Opmærksomhed. Jeg gjorde forleden en liden Tour i Vennekreds til Christiansfeldt, for at see de her værende Brødres Indretninger ${ }^{25}$. Paa Tilbagerejsen kom vi igjennem en Bye ved Navn Heils, som ligger omtrent en Miil fra Christiansfeld; dér fandt jeg en gammel ærværdig Bonde, som kalder sig Andres Pedersen, og er nu sine $70 \mathrm{Aar}^{26}$. Denne Mand er den største, den meest øvede Brokskjærer Danmark ejer eller nogensinde har ejet. Fra sit 22. Aar, har han beskjeftiget sig med denne Green af Chirurgien. I Begyndelsen ved at rejse omkring, men siden $i$ anførte Bondebye; hvor han paa egen Bekostning har indrettet et lidet Hospital med 6 Senge til Brokpatienter. Han skjærer for Brok medens de udtraadte Dele endnu kunne bringes tilbage; altsaa hvor ingen Incarceratio ${ }^{27}$ er tilstæde; $i$ en Tid af 4 Uger er Kuren gjerne fuldendt. Hans 6 Senge ere nesten bestandigen opfyldte. I de sidste 50 Aar har han saaledes opereret nogle 1000 , hvoraf kun et par skulle være døde under Kuren.

Om han bortskjerer en af Kaaderne ${ }^{28}$ kan jeg ikke sige med Vished, men dette veed jeg, at han ved det Held, hvormed han i saa lang Tid har skaaret for Brok, er i et ualmindeligt Raab. En kort Tid efter Kurens Fuldendelse raader han at bære et Brokbaand, og Recidiver skulle være rara avis in terra [en sjælden fugl på jord]. Han har en Søn paa 20 Aar, som lægger an paa at afløse Faderen i denne Haandtering; en anden, der kalder sig Gelzer, som nu er Præst i Jylland ${ }^{29} . "$

\section{NOTER OG HENVISNINGER}

1. Johan Daniel Herholdts fader, Johan Friedrich Wilhelm Herholdt, var født i Lützau i Mecklenburg i 1732. Han kom til Aabenraa i 1756. En af byens 3 kirurger Mathias Petersen var død i 1754, og hans uforsørgede enke havde ikke formået at få solgt privilegiet. Herholdt overtog det og lovede, at han ville gifte sig med den "umyndige og uforsørgede» datter Metta Catharina, hvilket skete i 1758. Herholdt blev borger i Aabenraa by i 1759. I ægteskabet var der to sønner, nemlig Mathias Peter og Johan Daniel. Efter konens død giftede han sig med Susanne Dorothea Lundten. Med hende fik han 5 børn. Nr. 3 i rækken var sønnen Johan Friedrich Wilhelm Herholdt (1778-1838). Han virkede som kirurg i København. Hans søn Johan Daniel Herholdt (1818-1902) var en meget kendt arkitekt. Johan Friedrich Wilhelm Herholdt døde i Aabenraa den 23.6.1782. Som det var skik dengang, giftede Herholdts enke sig med kirurgsvenden Nicolai Nielsen Dehnfeldt den 15.8.1783. Han overtog privilegiet, men forlod allerede Aabenraa to år senere.

2. Således har Olav Christensen benyttet den som kilde til en artikel om fysikus Schunk. Den fremkom i Sønderjysk Månedsskrift 1962. I sin bog "Sjukhus och fattigpolitik. Et bidrag til de 
danska sjukhusens historia 1750-1880«, København 1986, henviser S. Vallgårda til noten. Noten er ligeledes gengivet $\mathrm{i}$ Tage Grodums artikel „Embedslægevæsenet og fysici i hertugdømmet Slesvig indtil 1864«, der udkom i Dansk medicinsk historisk årbog 1986.

3. Medicinalforordningen af 4.12 .1672 var formelt galdende $i$ alle kongens riger og lande. Den blev dog først publiceret i hertugdømmerne i 1749, antedateret 1746, i lovsamlingen $w$ Corpus Constitutionum Regio Holsaticarum« (Hvidtfeldt s. 190-191). Forordningen blev ikke gengivet i sin helhed, men kun de andringer, der var tilføjet den oprindelige forordning. Dette var, efter daværende statsretslige principper, tilstrækkeligt for at hele loven havde sin gyldighed $\mathrm{i}$ hertugdømmerne. (Staatsbürgerliches Magazin Bd. 6, 1826, s. 709).

4. Ved forordning af 19.8.1757 blev hertugdømmerne Slesvig og Holsten opdelt i 10 fysikatsdistrikter. Et af disse var Aabenraa fysikatsdisktrikt bestående af de gamle Aabenraa og Løgumkloster amter. Fysikus (=embedslæge) havde bopæl i Aabenraa. (Chron. Samml. 1757 s. 15-16, Brix, s. 66-76).

5. Fysikus Friedrich Hinrich Wiggers var fadt i Krempe, Holsten, den 15.3.1746. Faderen Georg Wiggers (1712-1803) var læge og i perioden 1757-1789 fysikus i Husum. Efter forst at have studeret i København blev han dr.med. et chir. ved Kiels Universitet 1784, $i$ en efter datidens forhold fremskreden alder af 38 år. Året efter blev han fysikus for Aabenraa og Logumkloster amter, med bopæl i Aabenraa. Wiggers' mentale tilstand blev med årene mere og mere uklar og konfus, og han søgte derfor allerede i 1805 sin afsked, efter i 20 at have virket som fysikus. Ansøgningen blev ikke imødekommet. Først 1809 fik han sin afsked efter fornyet ansøgning. Hvorfor man, $\mathrm{i}$ en så betydningsfuld position, fastholdt en person der med årene afslørede flere og flere psykisk aparte træk, formentlig en paranoid tilstand, må stå hen i det uvisse. Wiggers dede 1811 .

6. Her hentydes der til, at der som forfatter til det store botaniske værk "Primitiae flora Holsatica«, der blev udgivet i 1780, bl.a. stod anført en person ved navn Fredericus Henricus Wiggers. Bogen var imidlertid skrevet af Georg Heinrich Weber (1752-1828). Weber var 1774 blevet dr.med. i Göttingen, 1777 extraordinær prof. i medicin og prosektor i Kiel. 1780 ord.prof, i medicin og botanik ved Kiels universitet. I 1788 grundlagde han på eget initiativ et mindre sygehus finansieret af private. Dette blev i 1802 overdraget universitetet. Samme år grundlagde han den store botaniske have, der blev tilknyttet universitetet. 1810 blev han udnævnt til direktør for det Slesvig-Holstenske Sanitetskollegium i Kiel, 1824 dr.phil. h.c. ved Kiels universitet. 1806 var han blevet udnævint til dansk etatsråd. (Volbehr \& Weyl s. 76-77).

7. Den første barber/kirurg vi kender navnet på i Aabenraa er Jens Balber, der i 1608 stod anklaget for at have deltaget $i$ uorden og spektakler. Han blev dog ikke idømt nogen straf. Den første barber med privilegium har nok været Jürgen Detlefsen (1582-1671). Han kom til Aabenraa 1610 , søgte straks om at måtte få et privilegium, men fik først sin første koncession 1614. Hans virkeområde var Aabenraa by og amt. I 1646 blev hans koncession delt, idet hans svigersøn fik den ene. Derefter har der i mange år virket to kirurger i Aabenraa. I 1744 fik en tredie kirurg lov til at virke $\mathrm{i}$ byen. Den tidligere dragon Matthias Petersen havde efter 20 års tjeneste fået stor viden inden for medicinen. Han var i 1745 til prove ved fysikus Bössel i Flensborg, og han fik af denne lov til at virke som kirurg. Matthias Petersen døde 1754 (se videre note 1). Med kirurgen Christian August Müllers død 1761 var der atter kun to kirurger i Aabenraa. Hans enke formåede nemlig ikke at fă afhændet mandens privilegium. (Aabenraa Byarkiv, VI nr. 86; M. Rasch s. 45).

8. Justus Zehr (1745-1806) var født i Keula, Thüringen, hvor hans fader også var kirurg. Zehr kom til Aabenraa i 1765 og giftede sig med kirurgen Martin Kier's datter. Han overtog svigerfaderens privilegium 1772. (Aabenraa Byarkiv, VI, nr. 86; M. Rasch s. 47).

9. Kirurgen Claus Hess overtog kirurgprivilegiet efter forgangeren Nicolai Nielsen Dehnfeldt $i$ 1785. Hess var fredt i Itzehoe i 1755 . Han var fra 1776 til 1777 eskadronkirurg ved et dragonregiment. Fra 1780 til 1782 sejlede han som skibskirurg med fregatten Christiana til Vestindien. Fra maj til sept. 1782 sejlede han med orlogsskibet Holstein. Derpå arbejdede han indtil han fik koncessionen i Aabenraa ved et infanteriregiment i Aalborg. Claus Hess virkede i Aabenraa indtil 1805. Herefter flyttede han til Tonder, hvor sønnen Heinrich Christian Hess (1791-1866) 
var distriktskirurg. Her døde han 14.10.1818. Claus Hess blev 1805 malet af Aabenraa maleren Jes Jessen iført skyttelaugets gallauniform. Det er et af de meget fă malerier af en kirurg i landsdelen. Originalen findes på Schleswig-Holsteinisches Landesmuseum, Schleswig. En kopi er anbragt på skyttegården i Aabenraa (H. Poulsen s. 129).

10. Med årstallet 1785 hentydes til, at Kirurgiske Akademi fik sin fundats ved forordning af 22.6.1785, der ophøjede Theatrum anatomicum chirurgicum til et akademi (Gotfredsen s. 247). Herved fik kirurguddannelsen faste rammer med en eksamen på en af universitetet uafhængig læreanstalt. For at sikre sig at kirurgerne fra hertugdømmerne også frekventerede det nye akademi, bestemte en forordning af 25.8 .1786 , at kirurger der fremtidig ville nedsæette sig $i$ hertugdømmerne skulle have eksamen fra akademiet $i$ København. Kirurger der allerede virkede i hertugdømmerne kunne fortsætte uhindret. Den forste kirurg der efter afsluttet eksamen ved kirurgisk akademi nedsatte sig i Aabenraa var Johan Peter Nissen. Han var født 1777 i Slesvig, hvor faderen var slotsforvalter. Nissen fik sin kirurgiske eksamen 1797, og han nedsatte sig kort efter i Aabenraa, hvor han havde sit virke indtil sin død 1811.

11. Wiggers' forgænger som fysikus i Aabenraa var Caspar Schunk (ikke Schonk). Han var døbt i Flensborg 15.8.1710. Faderen var smed, en for datidige forhold usædvanlig socialbaggrund for at blive læge. Han var blevet dr.med. i Wittenberg 1739. Han blev først fysikus i Aabenraa 1759, og døde sst. 3.10.1782. Schunk var dog ikke den første læge i Aabenraa, idet lægen Paul Christian Ambders havde praktiseret $i$ byen fra 1742-1750. Hans efterfølger blev Friedrich Fabricius (1731-1773), der var søn af den stedlige apoteker (se note 20). Fabricius virkede i Aabenraa fra 1757 til 1765, da han blev udnavnt til fysikus for Als og Ærø, med bopæl i Sønderborg.

12. Lorenz Heister (1683-1758) var professor i Altdorf, senere i Helmstedt. Han var en meget kendt kirurg og udgav bl.a. den meget benyttede "Chirurgie" 1718, der bl.a. var kendt for sine talrige illustrationer vedr. instrumenter, bandager og operationscener. Bogen blev oversat til talrige sprog. (Gotfredsen s. 246).

13. Der er god grund til at antage, at den gode læge har fået penge for sin lidet flatterende indsats. Et patent af 1.12.1820 "Betreffend die Erlassung einer Taxe für die den Aerzten und Wundaerzten zu entrichtende Vergütung für ihre ärztlichen und chirurgischen Bemühungen« bestemmer $i$ afsnit 1 pkt. $15 »$ Für die verlangte Gegenwart bei einer chirurgischen Operation, 3 Rigsbankdaler og 19 Rigsbankskilling«. (Chron. Saml. 1820 s. 167).

14. Barbernæringen var fri indtil 1501. Barberlavet i København fik sin første skrå 1505. Flensborg barberlav blev stiftet 1515 .

15. I slutningen af 1700-tallet praktiserede i Tender: Johan Gottfried Krichauff (1738-1806), Conrad Repsold (1747-1821) og Johan Heinrich Garmsen (1722-1810). Haderslev: Ernst Christian Hartmann (1729-?) og Johan Friedrich Schumacher (1768-1819). Sønderborg: Georg Heinrich Burchardi (1744-1821), Herlef Flensborg (1733-1784). Flensborg: Wilhelm Gottlob Lilie (1751-1804) og Gottlob Heinrich August Richter (1767 1842).

16. Nicolai Schmidt var født 1727, aflagde kirurgisk tentamen 1756 og kirurgisk eksamen 1760. Ifølge Carøe var Nicolai Schmidt den sidste kandidat som generaldirektøren for kirurgien Simon Crüger (1687-1760) eksaminerede. N. Schmidt var feltskærer 1760, regimentsfeltskærer i Holsten 1767. Herefter stabskirurg i Haderslev, hvorpå han praktiserede nogle år i Norge, for derpå at vende tilbage til Haderslev. Han var medlem af Kirurgiske Akademi 1789. Endvidere var han medlem af det Slesvig-holstenske sanitetskollegium fra dettes etablering 1804 indtil sin død 22.10.1806.

17. Johan Gottfried Krichauff var født i Görlitz, Sachsen, den 25.8.1738 og havde været feltskærer hos Frederik den Store. Han fik tilladelse til at drive praksis i Tonder i 1768 og blev i 1771 udnævnt til fysikus. I 1772 skal han være blevet dr.med., universitetet dog ukendt. I pietismens tidsalder formåede han at fă støtte hos Tønderborgerne til at bygge et mSygehus«. Bygningen stod færdig 1784 og står der såmænd endnu, den nuværende adresse er Østergade 15.

Han havde imidlertid forbygget sig og p.g.a. økonomiske problemer og vanskeligheder med byens borgere, der ikke syntes om at bo så tæt på et sygehus og fattiganstalt, måtte bygningen ophøre som plejeanstalt for syge og fattige. Krichauff blev afskediget 1802 bl.a. p.g.a. aftagende 
syn. Han døde den 4.12.1806. (Lars Henningsen, s. 341-356; Schleswig-Holsteinische Provinzialberichte, 1. Bd. 1787, s. 86-109).

18. Et af de vanskeligste og også absolut største epidemiologiske problemer i 1700-tallets Europa var koppesygdommen. Som forebyggende middel havde man dengang variolationen (=koppeympning), der var en forløber for koppevaccinationen. Ved variolation foretog man indpodning af pus fra humane koppepustler gennem huden eller næseslimhinden. Næseslimhinden blev af mange foretrukket som det sted, man foretog variolationen, idet ardannelsen dér ikke blev skæmmende. Ved variolationen pådrog man sig sygdommen i let grad, hvilket gav beskyttelse mod yderligere infektioner. Koppesygdommen kunne ofte forløbe fatalt. Den første læge i Hertugdømmerne, der foretog variolationen, var vist nok fysikus i Tønder Johan Christian Fabricius (1705-1775), der i 1754 foretog den på sine børn. De første læger, der foretog variolationen, og havde heldet med sig, blev berømte og erhvervede sig ofte stor rigdom.

Ved koppevaccinationen foretog man indpodning af pus fra ko-kopper $(\mathrm{ko}$, lat. = vacca). Den første læge, der videnskabelig beviste, at denne metode gav samme beskyttelse som variolationen og havde færre bivirkninger, var den engelske læge Edvard Jenner (1749-1823). Den første kokoppe-vaccination i Danmark blev i juni 1801 foretaget af kirurgen professor Frederik Christian Winsløw (1752-1811) på Kaningården ved Furesøen. (Erik Jacobsen, s. 138 og 140). Af lokal interesse kan man nævne, at prof. Winsløw blev assisteret af den stedlige distriktskirurg i Hørsholm, nemlig Johan Carl Holtzkamm (1762-1828). Holtzkamm virkede som regimentskirurg i Haderslev fra 1806 indtil sin død 1828. De første vaccinationsanstalter blev etableret $i$ København 1802, og 1805 blev der etableret en i Altona. Koppevaccinationen blev lovpligtig i Danmark i $1810 \mathrm{og}$ samtidig hermed blev variolationen forbudt. (Gotfredsen, s. 234-236).

19. For jordemodervæsnets fremme i Hertugdømmerne gjorde fysikus Georg Daniel Bössel (1704-1785) sig store anstrengelser. Bössel var blevet stads- og landfysikus i Hertugdømmet Slesvig 1732, dog med undtagelse af de tidligere etablerede fysikater i Haderslev, Tønder, Eiderstedt og Eckernförde. (Bestalling dateret 12.7.1732. M. Rasch, s. 42). Ved fysikatsreformen i 1757 blev han fysikus for Flensborg by og amt. Han havde på eget initiativ etableret en jordemoderskole i Flensborg 1755. Ved kongelig forordning vedr. jordemodervæsenet i Hertugdømmerne 1765 blev hans skole anerkendt som jordemoderskole for Hertugdømmerne. Samtidig blev der etableret en jordemoderskole i Altona. En stor del af æren for at denne blev etableret i Altona må tilskrives den daværende fysikus i Altona Johann Friedrich Struensee (1737-1772). (Winkle, s. 547). Ved forordning af 26.4 .1805 blev der etableret en jordemoderskole i Kiel for Hertugdømmerne. Herved blev institutionen i Flensborg nedlagt, hvorimod jordemoderskolen i Altona fortsatte som almindelig fødselsanstalt. G.D. Bössel udgav en lille, men meget læst bog med titlen »Grundlegung der Hebammenkunst für Wehmütter«. Den udkom 1759 i Altona. I forordet stillede han som ufravigelig betingelse, at jordemødrene kunne læse og skrive, når de påbegyndte deres uddannelse.

20. I Aabenraa havde der i tidens løb været flere tilløb til apoteksudsalg. Den første apoteker med privilegium var Thomas Fabricius (døbt 1688, død 1742), der den 24.8.1709 fik bevilling af hertug Karl Friedrich (1706-1761) til at etablere et apotek. I 1727 fik han kongelig bevilling. P.g.a. de angiveligt store etableringsomkostninger fik han lov til at drive vinhandel og krydderiudsalg sammen med sit apoteksudsalg. Dette var almindeligt for apoteker dengang, men medførte mange alvorlige konflikter med andre handlende i byen.

21. Hinrich Christoph Röseler var født i Barghorst, Ahrensbök, den 11.11.1716. Han tilhørte en kendt bøddelslægt i Holsten. Röseler blev 1743 ansat som bøddel af Aabenraa by og amt. (Snorrason \& Treichel s. 154). Han havde 1742 giftet sig med Anna Cathrina Stöckler (1725-1799), der var datter af skarpretteren i Tønder Joh. Christoph Stöckler. (Treichel s. 18). Udover sit fag havde Röseler nogen kirurgisk viden, som han udnyttede kommercielt, hvilket var årsag til stor vrede og utilfredshed hos kirurgerne. I 1780 indgik han forlig med kirurgerne om, at han fremover kun ville beskæftige sig med arm- og benbrud. Men han har nok ikke holdt sig til denne aftale, idet det kom til et dramatisk opgør i marts 1786. Aabenraa-kirurgerne havde forsamlet sig foran Rösslers hus og prøvede forgæves at komme ind i det. (Achelis: Heimatblätter 
s. 144). Husets nuværende adresse er Nygade 42. I gavlkvisten minder initialerne HCR endnu $i$ dag om den tidligere ejer. Rössler døde 9.4.1788. Han var den sidste bøddel i Aabenraa.

22. Degnen i Løjt, Hans Michelsen, var meget søgt som sygdomshelbreder. Fysikus Schunk, der kun var delvis lønnet af det offentlige og således var anvist på nogen privatpraksis, oplyser, at hans praksis var skrumpet fuldstæendigt. Han havde et år kun haft mellem 12-20 patienter privat. På foranledning af fysikus udstedte amtmanden derfor 1751 et forbud mod, at Michelsen fortsatte sine aktiviteter. Alligevel fortsatte Michelsen. I en skrivelse anfører Michelsen, at Schunk var lidet berømt for sin lægevirksomhed, medens Hans Michelsen, næst efter den guddommelige velsignelse havde lykken med sig. Michelsens speciale var undersøgelse af urinen, i hvilken han kunne diagnosticere alskens sygelighed. Når folk der opsøgte Michelsen burde have lægehjælp, henviste han dem til stiftfysikus i Ribe Anker Ankersen (1702-1760). (Hvidtfeldt, s. 188-189).

23. Den engelske urmager var medlem af den fra Liverpool i England indvandrede urmagerslægt Green. Det forste medlem af Green-familien i Aabenraa var Peter Green (1706-95). Han nævnes første gang i byens annaler i midten af 1740-erne. (H.V.Gregersen, s. 197). Han havde sønnen William (1733-1816), der ligesom faderen var urmager. Endvidere havde han en søn Jonathan (1740-1812), som man dog ikke ved meget om. Hvem der var aktiv som sygdomshelbreder vides ikke. Pulstagning har fra de aldste tider været anvendt som et vigtigt diagnostisk middel. Imidlertid har det forst været muligt at måle pulsfrekvensen på en nogenlunde sikker og reproducerbar måde, da man fik ure der kunne angive minutter. Det at få taget pulsen har utvivlsomt været en nyskabelse i Aabenraa i slutningen af 1700-tallet. (En engelsk urmagerslagt, der havnede i Aabenraa. Aabenraa Antikvitetshandel. Aabenraa, u.å.).

24. Her hentydes til en af den tyske Sturm und Drang-periodes mest læste forfattere, nemlig Johann Martin Miller (1750-1814), der i 1776 havde udgivet romanen "Siegwart, eine Klostergeschichte«. Romanen var udkommet et år efter Goethes "Die Leiden des jungen Werthers«. Millers tårepersende skrivemåde fandt mange efterligninger. Ingen af disse opnáede dog samme udbredelse som Millers bøger. (Kindlers Literatur Lexikon, Bd. VI, s. 1712),

25. Christiansfeld flække var uden for købstæderne en af de første bebyggelser i Hertugdømmerne, hvor der havde nedsat sig en lage. Christiansfeld var oprindelig bygget på den bare mark af brødremenigheden i 1773. (Herrnhuter-Samfundet, Bd. I, s. 43). Allerede 1782 nedsatte den første lage sig. Det var Nicolai Arbo (1723-1797). I begyndelsen af 1790-erne nedsatte kirurgen Joachim Dietrich Wiediger (1761-1843) sig i Christiansfeld.

26. Andreas Petersen var født i Mjolden nord for Tønder den 12.9.1724. I 1760 blev han gift $i$ Hejls med Karen Jørgensen fra Hejls. Han døde den 20.9.1799. Ved giftermålet overtog han svigerfaderens landejendom. Det var efter datidens forhold helt enestående, at han indrettede en lille afdeling til stationar behandling af de patienter, han havde opereret. I Haderslev byarkiv ligger indberetninger om Andreas Petersen fra sognepræsten i Hejls, Jørgen Jens A.Lassen (1713-1783), dateret den 10.1.1773. Fysikus Hartmann skriver i en indberetning dateret 11.3.1773, at han havde overværet en operation, og han mente ikke, at forholdene gav anledning til at skride ind mod broksnideren. Det nævnes, at Andreas Petersen blev opsegt af mennesker både fra Hertugdømmerne og fra Jylland og Fyn. (Haderslev Byarkiv og Haderslev Fysikatsarkiv).

27. Indklemning, hyppigst af indholdet i en broksæk.

28. Kaaderne $=$ Kotter? Kotter er en gammel betegnelse for sten (testikler). Se Otto Kalkar »Ordbog til det ældre Danske Sprog 1300-1700«, Bd. II. s. 608. Kobenhavn 1886-1892.

29. Sætningen virker underlig ufuldendt. Andreas Petersen havde en san ved navn Johannes Petersen Geltzer, der var født i Hejls den 8.10.1773. Han havde åbenbart intentioner om at følge $i$ faderens fodspor, men forholdene var blevet anderledes, som bl.a. antydet i note 10. Der foreligger såvidt vides intet skriftligt om denne sens aktiviteter. Man har indtryk af, at han har overtaget faderens landbrugsejendom og virket som landmand. I kirkebogen for Hejls står som stilling ved hans død anført gårdmand. Han døde den 8.6.1826. 


\section{TRYKTE KILDER}

Achelis, T. O.: Die Ärzte im Herzogtum Schleswig bis zum Jahre 1804. Kiel 1966.

Achelis, T. O.: Von Apenrader Scharfrichtern. Heimat-Blätter aus Nordschleswig 1940. S. 141-144. Bricka, C. F.: Dansk Biografisk Lexicon. Diverse bind.

Brix, J.: Lægevirke i Sønderjylland før 1864. Herning 1980.

Carøe, K.: Den Danske Lægestand. Bd. I-V. København 1909.

Chronologische Sammlung. Forskellige årgange.

Corpus Constitutionum Regio Holsaticarum. Bd. I-II. Altona 1749.

Dam, E. og A. Schæffer: De Danske Apotekers Historie. Bd. I-IV, 1925-47.

Dohrn, N.: Die Schleswig-Holsteinische Medicinalverfassung. Heide 1834.

Gotfredsen, Edv.: Medicinens Historie. 1. udg. København 1950.

Gregersen, H. V.: Om urmagerslægten Green i Aabenraa. Sønderjysk Månedsskrift. 39. årgang. 1963. S. $197-198$.

Henningsen, L.: Østergade $15 \mathrm{i}$ Tønder og dets beboere gennem 200 år. Sønderjysk Månedsskrift. 39. årgang. 1984. S. 341-356.

Hvidtfeldt, J.: Den nordslesvigske embedsstand 1700-1800. Sønderjyske Årbøger 1958. S. 101-222.

Jacobsen, E.: Kopper og vaccination. Medicinsk Forum. Nr. 5., 40. årgang. 1987. S. 137-143.

Kindlers Literatur Lexikon. Zürich 1971.

Kähler, J.: 200 Jahre Apenrader Schützengilde 1734-1934. Aabenraa 1934.

Kordes, B.: Lexikon der jetztlebenden Schleswig-Holsteinischen und Eutinischen Schriftsteller. Schleswig 1797.

Lübker, D. L., Schröder, H.: Lexikon der Schleswig-Holstein-Lauenburgischen Schriftsteller von 1796-1828. Altona 1829.

Poulsen, H.: Jes Jessen. Maleren fra Aabenraa. Aabenraa 1971.

Rasch, M.: Von den Barbieren, Chirurgen und den ersten gelehrten Medizinern in der Stadt Apenrade. Die Heimat. 58. Jahrgang. 1951. S. 37-49.

Snorrason, E., F. Treichel: Tønderskarpretteren Johann Christoph Stöckler's Slægtsforbindelser. Personalhistorisk Tidsskrift. 90. årgang. 1970. S. 153-163.

Thyssen, A. P.: Herrnhuter-Samfundet i Christiansfeld. Aabenraa 1984.

Treichel, F.: Das Scharfrichtergeschlecht Röseler. Familienkundliches Jahrbuch Schleswig-Holstein. Jarhrgang 6. Kiel 1967. S. 11-25.

Winkle, S.: Johann Friedrich Struensee. Arzt, Aufklärer und Staatsmann. Stuttgart 1983.

Volbehr, F., R. Weyl: Professoren und Dozenten der Christian-Albrechts-Universität zu Kiel 1665-1933. Kiel 1934.

\section{UTRYKTE KILDER}

Kirkebøger Hejls og Aabenraa. Landsarkivet Aabenraa (LA Aa).

Haderslev byarkiv Nr. 67., Medicinalsager 1-3. Fysikus, Læger-kirurger, Apotekere. (LA Aa).

Haderslev fysikatsarkiv, fysikatsanliggender 1757-1820. Pk. 9 (LA Aa).

Aabenraa byarkiv. VI, nr. 86 (LA Aa). 


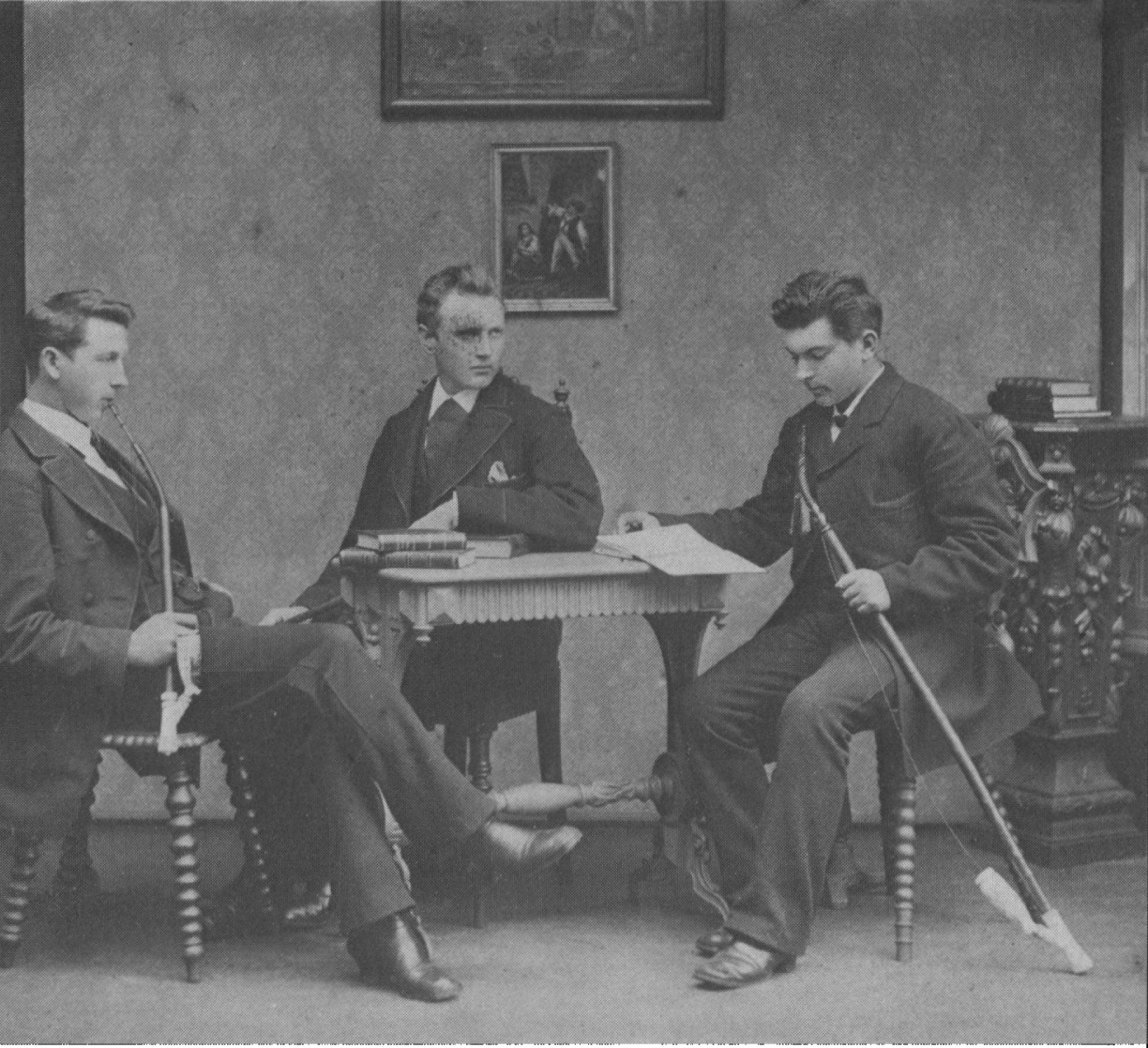

Danske og tyske "seminaristuniformer":

$I$ de to forste artier efter 1864 var Tonder Seminarium delt $i$ en dansk og en tysk afdeling. I 1884 fyttede den danske afdeling til Haderslev, og seminariet $i$ Tonder blev rent tysk. De tyske elever bar både for og efter 1884 uniformer efter forbillede fra de tyske "Studentenburschenschaften". Hyppigt lod de sig fotografere i dette antrak, således som det ses nedenfor side 75 og 81 . Også i den danske afdeling havde man - som Hans Chr.Iversen fortaller $i$ de i det folgende gengivne erindringer optaget enkelte studentikose skikke. Det galder de barske rusoptagelsesceremonier. Dem havde Iversen dog held til at fá afskaffet $i$ sin formandstid $i$ den danske seminaristforening "Harmoniw. "Harmonik var en forlaber for den danske seminaristforening "Enigheden", som Iversens svoger, den senere viceskoleinspektor $i$ Kobenhavn N.P.Olsen var den sidste formand for. "Enighedensw medlemmer optog ogsd skikken at bruge en bestemt hue, dog ikke den samme som de tyske seminarister. Oprindelig var foreningens medlemmer udstyret med en gron hue, og $i$ slutningen af 1870 'erne blev den ombyttet med en, der lignede den danske studenterhue. Den vakte forargelse både blandt de tyske seminarister og Tonders tyske borgerskab, og det endte efter en shuekrig" med, at huen blev forbudt $i 1878$.

Desvarre synes der ikke at vare billeder bevaret af danske seminarister med huen. De har tilsyneladende ikke ladet sig fotografere $i$ samlet flok som deres tyske faller, jvfr. s. 75 og 81. På billedet her er tre af de danske seminarister foreviget $i$ civilt antrak $i$ l. A. Bodewadts fotografiske atelier $i$ Tonder. Til en seminarists udstyr horte uvargerligt den lange pibe. Af de tre oven afbildede seminarister kendes kun den midterste, nemlig N.P.Olsen. Foto i Historiske Samlinger. 